\title{
Co-evolution of Policy and Emerging Technology: Hydrogen Energy Policies in Iceland, the United Kingdom, and Korea
}

\author{
Sangook Park*
}

\begin{abstract}
This article explores the relationship between science and technology, on the one hand, and science, technology, and innovation policy, on the other. It argues that interactions between them involve a co-evolutionary process that varies with national systems of innovation. To find real-time evidence for this, an emerging technology was chosen for analysis, namely hydrogen energy technology. Various systemic perspectives aim to show how the development path of a technology is shaped by different interests and relations within society. This article demonstrates the existence of a co-evolution pathway that varies, depending on a country's innovation system, mediated by governance structure. National systems of innovation strongly affect the co-evolution pathway depending on their particular needs, limitations, and circumstances. The findings support the recently proposed interactive model of science, technology, and innovation policy making, which includes an interactive learning process and working policy networks of stakeholders including researchers, policy makers, and civil society.
\end{abstract}

Keywords: co-evolution, science and technology policy, hydrogen energy, national innovation systems

\section{INTRODUCTION}

Not only in biology but also in social science, the concept of evolution has been widely applied in recent years. This is especially true in studies of innovation, with such developments as evolutionary economics, innovation system theory, and socio-

\footnotetext{
* Sangook Park is a research fellow in the Asia Development Institute, Graduate School of Public Administration, Seoul National University. His research interests include development cooperation, sustainable energy policy, and science, technology, and innovation policy. Email: sangook.park@gmail.com. The author is grateful to three anonymous referees, whose comments substantially contributed to improving this paper.
}

Manuscript received February 10, 2011; out for review February 26, 2011; review completed March 29, 2011; accepted April 8, 2011.

The Korean Journal of Policy Studies, Vol. 26, No. 1 (2011), pp. 117-143.

(C) 2011 by the GSPA, Seoul National University 
technical system theory. Evolutionary approaches have frameworks consisting of such elements as variation, competition, selection, and retention, and they emphasize the complexity of continuously changing economic systems and the weakness of conventional belief in the notion of equilibrium in mainstream economics (Nelson \& Winter, 1982; Metcalfe, 1998).

Although the notion of co-evolution can be found in much older writings in various fields, its most relevant use in this context began when it was introduced into evolutionary economics. We must be careful not to use the term too broadly, as meaning "evolving together at the same time." As Rip (2002) has pointed out, "Co-evolution is often used as a broad characterization of co-development and mutual shaping, without specific reference to evolutionary theory."

In evolutionary economics, one of the first to introduce the co-evolution concept was Nelson, who applied it to changes in industrial structure and in technology during the product lifecycle (Nelson 1994, 61). ${ }^{1}$ Co-evolution was described as "the relationships between the evolution of a technology and the evolution of firm and industry structure"-in short, "the relationship between evolutions." However, few researchers paid much attention to this concept before the socio-technical system perspective was introduced. (This perspective is complex enough to incorporate the co-evolution concept.) Rip and Kemp then applied the co-evolution concept to the relationship between technology and society (Rip \& Kemp, 1998). Geels has been keen on using this concept, which he has described as emphasizing "seamless webs, emerging linkages between heterogeneous elements and co-construction (actor-network theory, social construction of technology, large technical systems theory)" (Geels, 2004, 909). ${ }^{2}$

Genuine co-evolution involves several factors: First, the actors and components that co-evolve are varied. Second, their interaction results in changes for all of them. Third, there occurs a converging pattern of evolutions, which is reasonably explainable. In addition, co-evolution occurs in a certain environment - a landscape, regime, or space-in which the co-evolving actors have been located over time.

This article investigates the co-evolution of hydrogen technology and STI (science, technology, and innovation) policy, each reacting to and being influenced by a particular national innovation system (NIS). Recently, the concept of co-evolution has been applied

1. Nelson used the term co-evolution to demonstrate the obsoleteness of formal models of economic change that are formulated in terms of a cause (the independent variable) and a result (the dependent variable), with the result that they cannot provide an adequate explanation of a complex phenomenon, such as changes in technology and industrial structure and subsequent economic growth.

2. Geels uses the notion of construction in the same manner as sociologists of science and technology. 
to the above terms by a number of researchers. Hekkert, van Giessel, Ros, and Wietschel (2005) have written about the evolution of hydrogen research in Germany; Jeeninga and Kets (2004) have reported on the evolution of Dutch energy policy; Mytelka and Smith (2002) have showed the co-evolving process of innovation theory and policy; Rip (2006) has adopted a co-evolutionary approach to governance; and Jacobsson and Bergek (2004) have analyzed the evolution of technological systems in renewable energy technology. This article offers empirical examples of the influential role of the NIS as a co-evolutionary environment. Together with an extensive analytical framework, the results will reveal aspects of the NIS that shape co-evolutionary pathways with different patterns of co-evolution.

\section{THE CHANGING RATIONALE AND DEVELOPMENTAL MODES OF STI POLICY}

It has become common to refer to STI policy as a whole, instead of looking at it as separate science, technology, and innovation policies. However, these policies may be seen separately in a certain sense, because each has its own characteristics and historical background. It was in the late 19th century that a few scientists first claimed that science should be a matter of national attention. Pasteur (1871) wrote about French research conditions at the time, and called for better national science and education policies. In the United Kingdom, Gore (1882), a chemist, argued that science was the key to national progress and demanded that the government promote original scientific research. During the two world wars, it was realized that a country's scientific performance had a direct connection with its military power. Therefore, the large-scale, systematic and national support of science began. ${ }^{3}$ Vannevar Bush's 1945 report Science, the Endless Frontier demonstrated that era's optimistic attitude toward the promotion of science.

The rise of technology policy and of related industrial policy was accompanied by the dimming of the belief that promoting basic science would result in useful output. Although there was an important move to link science with economic growth in the 1960s (OECD, 1963), it was soon recognized that government policy, along with the systemic management of investment and the evaluation of research and development

3. One of the first modern government organizations responsible for scientific research was the Office of Scientific Research and Development in the United States, established in 1941, which followed the more defense-oriented National Research Council (established in 1917) and the National Defense Research Council (established in 1940). 
(R\&D) activities, could provide better outputs. The rapid catch-up achieved by Japan was thought to have been enabled by well-organized and strategic government policies on technology and industry. The role of government was expanded from funding science to linking scientific achievement to commercialization, creating strategies for technological advancement, managing public-private partnerships, and sometimes steering the direction of research and improving national institutions.

Although neoclassical economics has struggled to explain the relationship between technological change and economic growth, innovation policy has been a legitimate part of economic policy since the 1980s (OECD, 1980, 1991, 1992). It is almost impossible to distinguish innovation policies from economic policies, or even from general public policies, because they all concern human capital, social capital, health and safety, ethics, overall economic performance, and the creation, management, and flow of knowledge. In short, it is possible to argue that innovation policy includes science and technology policy. Since the beginning of the 21 st century, innovation policy has provided a broader perspective than before, becoming one of major issues on international agendas concerned with the knowledge economy and sustainable development (European Commission, 2002).

Specific and strategic technology and industrial policies are still very strong in some countries, such as Taiwan and Korea (Kim, 1993; Kim \& Nelson, 2000). Consequently, we could use the terms science, technology, and innovation policy, instead of the universal term innovation policy. But there are several reasons why it may be better to think in terms of STI policy as a whole rather than thinking of its components separately. Firstly, science, technology, and innovation are closely related and interact with each other, and it is always desirable to see the whole picture. Secondly, recent scientific advances are making the distinction between science and technology obsolete, especially in cases such as nanotechnology and biotechnology, which are not totally distinguishable from physics, chemistry, and the biosciences. These fields have emerged from the convergence of various academic fields. Thirdly, studies of STI policy have become legitimate, and most people who deal with related issues understand the term STI policy and accept it as standard.

STI policy can be characterized as organized activities of a government, such as the public funding of research, investment in industrial $R \& D$, innovation in consumer goods and services, and changing priorities for science and technology (Freeman \& Soete, 1997), with the aim of developing science and technology and enhancing competitiveness - that is, strengthening the innovative capability of a nation. STI policy has a broad range. In former times, it was aimed at promoting basic science, stimulating innovation, and facilitating the application of the innovations. In recent years, it has often been assumed that the primary objective of STI policy is to strengthen a 
country's competitiveness with regard to science and technology.

Since the late 1970s, STI policy researchers have begun to deal with the economic aspects of innovation, such as the relationship between STI and economic growth and the efficiency of R\&D investments. This trend has led to the concept of the system of innovation, and since then, STI policy has covered not only STI but also the whole innovation system, including its institutions, organizations, and learning mechanisms. Innovations and socioeconomic development are not separate but interact with each other, which opens up the possibility of an explanation of socioeconomic change from an evolutionary viewpoint.

STI policy has been concerned not only with economic aspects but also with social and cultural aspects. In the early 1970s, social and human considerations were also taken into account within STI policy, and this resulted in a broadening of the field (OECD, 1971). It is thought that the increasing attention to the subject of science, technology, and society influenced the broadening of STI policy objectives in that era. The early proponents of the innovation system perspective never ignored the broader social and cultural aspects of STI.

In a number of previous STI policy studies, quite a few terms have been used to represent the demand side, including consumers, users, the general public, and people, chosen in accordance with the author's viewpoint on either economics or public administration. Conversely, the supply side can consist of scientific researchers, the manufacturing industry, and service providers. In a subfield of sociology that focuses on science and technology, researchers have been emphasizing public perceptions of science and technology and citizen's participation in STI policy making in a manner of deliberative democracy and the "governance of science" (Fuller, 2000). More recently, risk management concerns have caused a growing demand for research, since interest in food safety and potential health risks is increasing (Zwanenberg \& Millstone, 2005). A similar phenomenon has occurred in bioethics because of rising concerns about humanity in the field of bioscience. In this sense, the number of fields with which STI policy is concerned is growing continuously.

Sustainability is another major issue in STI policy. Public concern over energy security first rose after the two oil crises in the 1970s. Although the correlation was not strong, the environmental movement changed the public's perception of the environment, especially in Europe. Since the mid 1990s, the perspectives of risk management and sustainability have been combined by the threat of climate change, more popularly known as global warming. The aim of reducing the production of carbon dioxide, a greenhouse gas, is not only to prevent or delay climate change, but also to ensure more efficient use of energy resources, and hence to achieve a lower carbon economy. The global issue of climate change has brought together not only people 
who are concerned with energy and the environment, but also natural scientists such as meteorologists and geologists, who have long been believed to be value-neutral. Since this issue attracts wide public engagement, the social, cultural, and even political aspects also need to be taken into consideration.

To achieve a lower carbon economy, which is assumed to have greater environmental friendliness, better energy efficiency, and an affordable degree of climate change, the wide-scale use of new and renewable energy sources is necessary. However, as the term itself reveals, these are not conventional energy sources, which means most technologies for new and renewable energy use are not yet mature enough, let alone socially accepted and financially cost-effective. A big part of new and renewable energy policy involves research, development, and demonstration, which has called STI policy to the center of sustainable energy policies.

In recent decades, a number of systemic perspectives have been developed not only by STI policy researchers but also by science and technology researchers. Technological system theory (Hughes, 1983, 1989) aims to show how the development path of a technology is shaped by various interests and relations within society. The systemic elements not only of technical system theory but also of innovation system theory emphasize the supply component of technology and innovation. There have been efforts to extend technological system theory to a new concept of systems that is constructed on the basis of an ensemble of technologies and society (Kemp et al., 1998; Geels, 2002, 2004). Socio-technical system thinking emphasizes the broader participation of the various social constituents and the interaction between technological developments and society with regard to institutions within the technological regime and its environment. It is evident that socio-technical system theory has been influenced by technological system theory, actor-network theory, and a number of innovation system perspectives that focus, for example, on national or sectoral innovation.

As climate change has become a global issue, some STI policy researchers have suggested that the transition to sustainability should be achieved, and that science and technology will play an essential role in the transition. Since the transition to sustainability involves various systemic changes not only in technological systems but also in society, sustainability concerns have catalyzed the convergence of various social and technological system-perspectives. STI policy can be developed with regard to the strategic management of the transitions, which is denoted as strategic niche management, since most sustainable technologies are now located at the niche level of sociotechnical transition (Kemp et al.; 1998; Kemp et al.; 2001).

Hydrogen technology, the focus of this article, is a good example of an emerging technology. Many countries have prepared, or are about to prepare, a policy on the hydrogen economy, including an R\&D policy. Third, hydrogen technology involves a 
transition of the energy system that cannot be considered without also examining wider social influences, which means we should look at a number of actors and stakeholders such as civil society, nongovernmental organizations, and, of course, industries, unlike in the case of basic science.

\section{THEORETICAL FRAMEWORK}

\section{Three National Innovation Systems and Socio-technical Transitions}

The NIS perspective has been widely used in STI policy research to analyze innovative performance and its policy implications. An NIS usually consists of various tangible or intangible components such as science and technology (S\&T) organizations, firms, institutions, and market conditions. All the system components continuously interact with each other, and the interactions can be regarded as learning processes, which results in the term interactive learning. An NIS is best seen as a dynamic mechanism of knowledge creation, flow, and utilization, rather than a static snapshot. Figure 1 presents a basic conceptualization of NIS, but the details differ from one country to the next.

Figure 1. National Innovation System

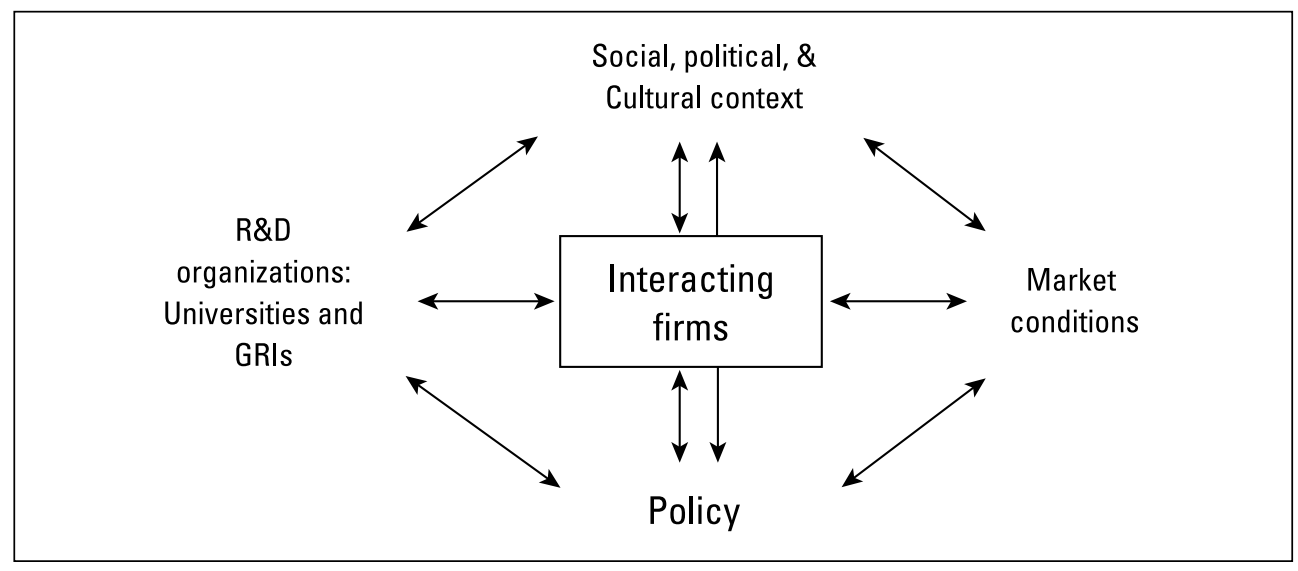

This study explored the ways that different NISs shape the co-evolutionary pathways of technology and STI policy. It involved observation of the co-evolution of the emerging hydrogen technology and STI policy for it. To see a clear contrast and to perform an appropriate comparison, countries were selected for the study based on the 
following differences in their NISs: available resources, including the R\&D budget; innovation capabilities and level of technological progress; social acceptability and facilities for the energy transition; the nature and extent of government intervention; and each nation's strategy with regard to whether it is leading or catching up. Thus, we can connect national systems of innovation for each country to the observed pattern of technology-policy co-evolution in the early stages of the hydrogen transition. Iceland, Korea, and the United Kingdom were selected for study.

Iceland is an example of a living-scale socio-technical experiment, which is made possible by its small society and unique natural environment. Iceland's simple governance structure makes it is possible to develop and implement a hydrogen policy effectively and provides controlled experimental conditions. Iceland has an advantage in terms of social acceptability, which is one of the key factors in any socio-technical transition.

Korea has been catching up successfully in terms of economic growth, especially in certain manufacturing industries characterized by rapid technological development. People in Korea see hydrogen more as an opportunity for new industrial development than in terms of environmental considerations. Korea has just begun to put hydrogen energy at the center of its energy and STI policies, having become convinced by the hydrogen fuel initiative in the United States in 2003. Korea's strategy is based on concentrating its resources on a few selected technologies, reinforced by large firms and supported by strong government intervention. Not only technologies but also policies are developed in a catching-up manner, and the Korean government is still leading this process. Because Korea developed late, not much attention has been paid to policy research and societal considerations.

Climate change is one of the most significant concerns in the wider socio-technical landscape, and its threat has been mobilizing government action and policy research on hydrogen energy. It is generally understood in the United Kingdom that hydrogen energy can help reduce carbon emissions. Because the United Kingdom has a larger economy and a more complex society, the hydrogen economy cannot be a dominant blueprint for its future, so it is considered as just one of several efforts toward sustainable development. R\&D activities may seem to be fragmented, because there has been neither strong government intervention in industrial $R \& D$ nor national research institutes. However, there may be changes since the UK government plans to establish an Energy Technology Institute, which will be accompanied by the Energy Research Partnership. Policy research is very active and includes the development of sociological and socio-technical perspectives.

It was possible to find an interesting case from Iceland, and to see a clear contrast between Korea and the United Kingdom. Findings there support the hypotheses that 
the NIS constitutes the co-evolutionary regime of the emerging technology and STI policy. The types of evidence consulted for this study are listed in table 1. Fieldwork was carried out in all three countries, ${ }^{4}$ and a total of 41 qualitative interviews were undertaken. Research consisted of document surveys, interviews, and other direct and indirect observations.

Table 1. Evidence Consulted during the Study

\begin{tabular}{|c|c|c|c|}
\hline Evidence & Iceland & Korea & United Kingdom \\
\hline Documentation & $\begin{array}{l}\text {-Government } \\
\text { announcements } \\
\text { - Government reportsa } \\
\text { - The national hydrogen } \\
\text { energy roadmap } \\
\text { - Policy research papers } \\
\text { - Brochures and meeting } \\
\text { materials } \\
\text { - Newspaper articles }\end{array}$ & $\begin{array}{l}\text {-Government } \\
\text { announcements and other } \\
\text { documents } \\
\text { - The national hydrogen } \\
\text { energy roadmap } \\
\text { - Technology forecasting } \\
\text { report } \\
\text { - Policy research papers } \\
\text { - Newspaper articles } \\
\text {-W ebsites }\end{array}$ & $\begin{array}{l}\text { - Government responses } \\
\text { - Strategic hydrogen energy } \\
\text { roadmap } \\
\text { - Policy research reports } \\
\text { - Technology forecasting } \\
\text { reports } \\
\text { - Academic journal articles } \\
\text { - Newspaper articles } \\
\text {-Websites }\end{array}$ \\
\hline Interviews ${ }^{b}$ & $\begin{array}{l}6 \text { interviews, all face-to- } \\
\text { face }\end{array}$ & $\begin{array}{l}17 \text { interviews, mostly face- } \\
\text { to-face }\end{array}$ & $\begin{array}{l}18 \text { interviews, mostly face- } \\
\text { to-face }\end{array}$ \\
\hline $\begin{array}{l}\text { Direct } \\
\text { observation }\end{array}$ & $\begin{array}{l}\text { Visits to hydrogen energy- } \\
\text { related sites, including the } \\
\text { hydrogen fuelling station, } \\
\text { fuel cell bus garage, and } \\
\text { the Icelandic New Energy. }\end{array}$ & $\begin{array}{l}\text { Visits to the hydrogen fuelling } \\
\text { station, } R \& D \text { labs, and } \\
\text { funding agencies }\end{array}$ & $\begin{array}{l}\text { Visits to } R \& D \text { labs and policy } \\
\text { research institutions }\end{array}$ \\
\hline
\end{tabular}

\section{Socio-technical Transition and Co-evolution of Emerging Technology and STI Policy}

The key components of the innovation system can be represented as institutions, organizations, and networks. Components of institutions include laws, regulations, and culture; organizations include government, firms, nongovernmental organizations, and agencies; and the networks category can be subdivided into markets, industrial sectors, policy networks, and all other mechanisms and systemic structures. These components

4. This project, including fieldwork, was self-funded. 
constitute not only an innovation system but also a socio-technical regime, in which the components evolve together.

Figure 2 represents the socio-technical regime as a space in which the co-evolution of system components takes place over time, and the terminology of the components is not very different from the terms used in innovation system theory, within which the concept of co-evolution has been generally accepted and is often denoted as involving interactive learning. All the components are cross-linked to form a network in which they interact continuously. Innovation system theory has focused on explaining different patterns of economic growth, which depend on the characteristics of the innovation systems in different nations, while socio-technical system theory has been developed on the basis of technical system theory, which is generally adapted to support the social shaping of technologies. However, those two theoretical frameworks have many terms in common. It should be possible to combine those two frameworks, and to show that different innovation systems influence the shape and transition paths of socio-technical systems in different ways.

Figure 2. M ulti-level Perspective on Transitions

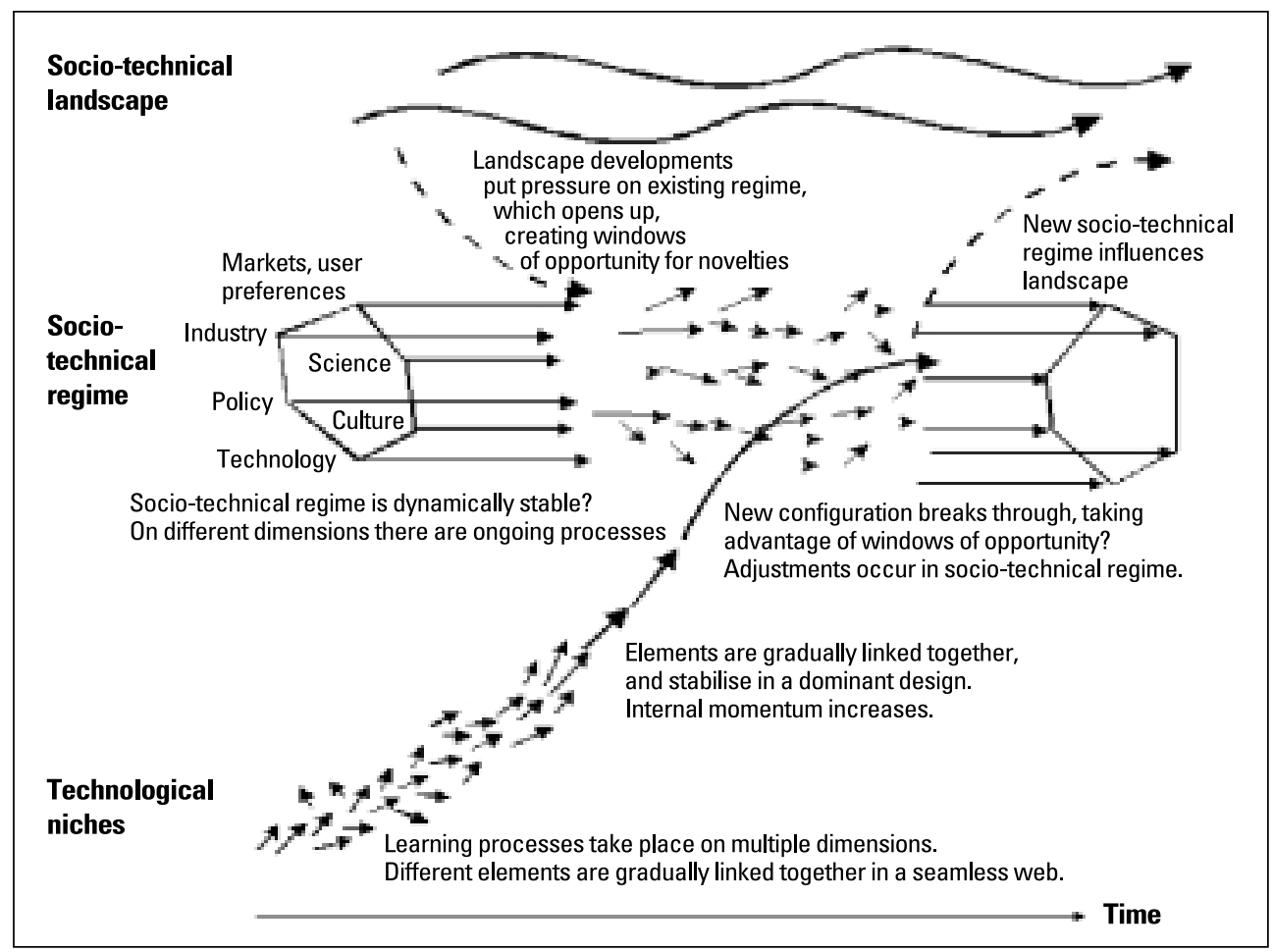

Source: reproduced from Geels, 2004. 
Many components, not just those mentioned above, co-evolve. This means not only evolving at the same time, but also interacting with each other to affect and shape each other, resulting in quite complex systemic changes (Rip, 2006). To avoid becoming too complex, this study focuses on the co-evolution of new technology and STI policy, using the conceptual framework presented in figure 3. The two solid lines denote the evolutionary paths of an emerging technology and its associated policy, and the dashed line denotes governance. This diagram shows the concept of co-evolution between an emerging technology and the associated technology policy, influenced by the governance system as a mediator.

Figure 3. Co-evolution of an Emerging Technology and Its Associated Policy

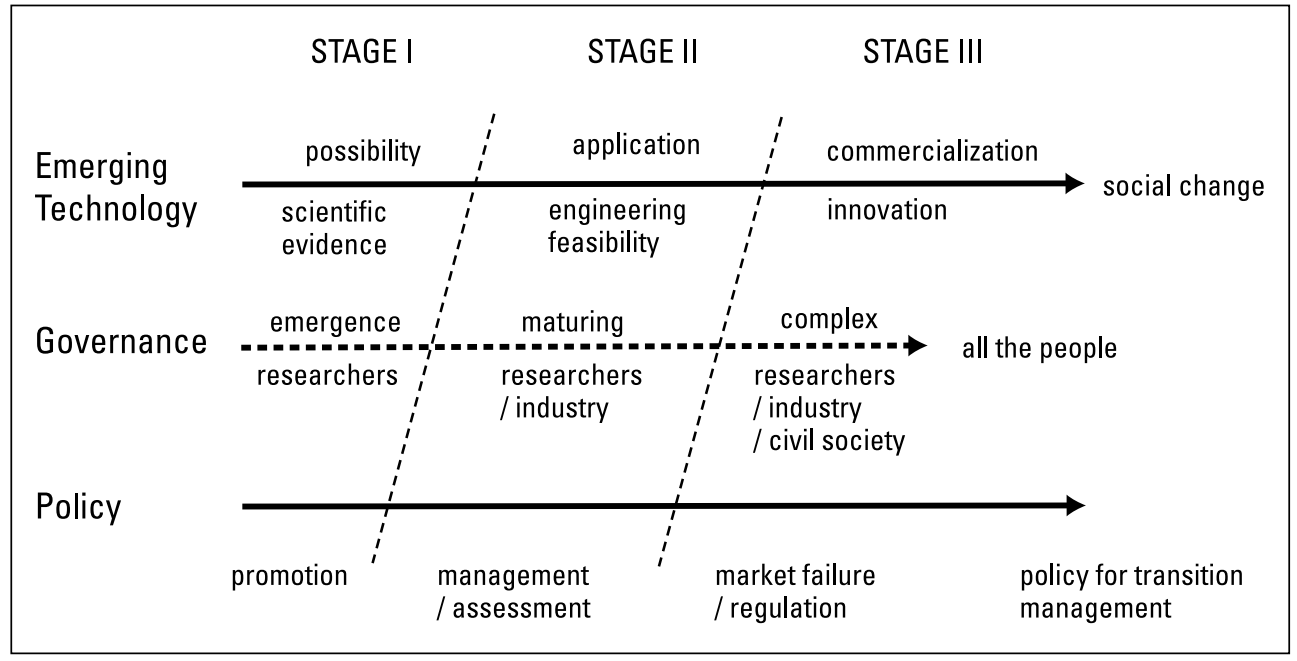

The suggested model for the evolution of STI policy consists of the following stages:

- Stage 1 - promotion of a promising new technology by funding, followed by technology forecasts

- Stage 2-management of ongoing R\&D programs, including evaluation of outcomes and assessment of social impact

- Stage 3-development of the rules of the market, such as regulation, steering, and public relations

Just as NISs differ across countries depending on their cultural and historical differences and their respective paths of technological development, so can the path of the co-evolution of technology and policy vary across countries depending on their 
economic circumstances and technological capabilities and the social acceptability of the new technology. The system of innovation operates as a space for the co-evolution of socio-technical regimes, and the landscape (see figure 2) is the environment that interacts with regimes. In the case of hydrogen energy transition, global warming, changes in oil prices, global agreements like the Kyoto Protocol, and other countries' policies are all examples of what constitutes the landscape.

As mentioned previously, the NIS shapes the co-evolutionary pathway. In other words, it can be regarded as an environment of co-evolutionary process. Strong S\&T organizations produce scientific knowledge and technological advances to propel the evolution of technologies, which demand STI policies for promotion and management of technological changes. In addition, since S\&T organizations are major actors in the STI policy network, they participate in developing the policies that they demand. Firms, being closer to the market than S\&T organizations, also contribute to technological changes, and demand government policies for nurturing infant industries and subsidizing industrial R\&D. Competition rules, regulations, industrial standards, and intellectual property rights protection are needed as well, though they are not directly demanded by firms.

Table 2. NIS Components and Factors that Shape the Co-evolutionary Pathway

\begin{tabular}{l|l|l}
\hline \multicolumn{2}{c|}{ NIS components and factors } & \multicolumn{1}{c}{ Influences on co-evolutionary pathway } \\
\hline \multirow{4}{*}{ Actors and netw orks } & S\&T organizations & S\&T development, policy demand \\
\cline { 2 - 3 } & Firms & Technological development, policy demand, products \\
\cline { 2 - 3 } & Government & Policy development, transition management \\
\cline { 2 - 3 } & Stakeholders' networks & Policy demand, social selection \\
\hline \multirow{2}{*}{ M arket and demands } & Industry structure & Social selection, advantages and limitations \\
\hline \multirow{4}{*}{ Capabilities } & Social and cultural context & Social acceptance, development experience \\
\cline { 2 - 3 } & Legislation and policies & Objectives for analysis \\
\hline \multirow{2}{*}{ International factors } & R\&D & Strengths and weaknesses \\
\cline { 2 - 3 } & Demonstration and deployment & Social acceptance, rate of evolution \\
\cline { 2 - 3 } & Innovation and commercialization & Strengths and weaknesses \\
\cline { 2 - 3 } & International bodies and treaties & International politics, agenda \\
\hline
\end{tabular}

The stakeholders' network is often a very strong policy network that is keen to influence government policies to become more beneficial to the participants of the network. Industry structure may determine the strength and limits of innovative capabili- 
ties in a certain technological field, which affects priority setting, that is, the strategic focusing of government policy. An international landscape made up of elements such as scientific advancement, global environment, and international politics is generally shared by different countries; however, the extent to which a country is influenced by it may vary depending on the characteristics of its NIS. Table 2 summarizes the way that components and factors of an NIS influence the co-evolutionary pathway.

Regarding the mediator of the co-evolutionary process, the model used in this study assumes that a governance structure consists of actors and their cooperation, and its purpose is to control or guide the co-evolution pathway. In the early stage of a new technology, there may emerge a relatively simple governance system involving a small number of actors. As the technology develops, the governance structure generally becomes more complex and more society-related, with more actors and more controversies.

At stage I, the possibility of a certain scientific finding or an emerging technology is known to only a small number of experts, so the governance structure is relatively simple, consisting of researchers and government officials. At this stage, senior scientists are normally the key players, acting as advisers to the government (Glynn, Flanagan, \& Keenan, 2001). At the next stage, the departments or ministries in government begin to perform organized activities such as technology planning and program management, and at this stage STI policy researchers may also support policy development, making predictions and providing systematic thinking. By the third stage, most people in society are aware of and starting to use the new technology and are also affected by it. Thus, civil society actors become involved in the governance structure, though some of the actors may have been involved in earlier stages.

The final stage of the co-evolution of technology and policy involves the development of a new socio-technical system in which the technology affects most people in society, which is thus reshaped by the technology. A government has to prepare a policy for managing the transition from the old system to the new one. At this stage, a system-builder is needed to develop a new socio-technical system, someone who plays a role in directing the re-shaping. No one person or single organization will be able to carry out this role, but a good governance system is needed.

This model may appear linear at first sight, but it is not. The arrows and directions represent a general tendency over time, but they do not always come to realization. This study demonstrated that the stages do not necessarily appear sequentially, and they can even be mixed, depending on the NIS. In addition, since this is a co-evolutionary process, it is worth stressing that all the components interact with each other, so it is not appropriate to separate independent and dependent variables, or causes and consequences, although one does need to investigate how the co-evolutionary environ- 
ment - the NIS as a co-evolutionary regime — shapes the pattern, and steers the path, of co-evolution.

\section{RESULTS AND DISCUSSION}

\section{Comparison of the Three National Innovation Systems}

A complete analysis of each NIS is not required for this discussion; instead, some key characteristics are presented for comparison. All three countries are members of the OECD (Organisation for Economic Co-operation and Development), making it possible to obtain data that have been prepared by standard measure. Table 3 present Iceland's NIS, which can be characterized as follows: (1) limited financial resources and R\&D capacity, particularly in the manufacturing sector, due to its small size; (2) a highly educated population in a small geographical area; and (3) the extreme importance of foreign actors for R\&D.

Table 3. Strengths and W eaknesses in Iceland's Innovation System

\begin{tabular}{l|l}
\hline Strengths & Weaknesses \\
\hline Above-average R\&D expenditure as a share of GDP & Limited financial resources in absolute terms (size \\
$\begin{array}{l}\text { Companies' high scores with respect to non-technical } \\
\text { innovation }\end{array}$ & $\begin{array}{l}\text { limitation) } \\
\text { Limited overall research capacity }\end{array}$ \\
$\begin{array}{l}\text { Companies' success in finding foreign partners for their } \\
\text { R\&D efforts (perhaps due to absence of local capacity) }\end{array}$ & $\begin{array}{l}\text { Fragmentation of industry due to small size and small } \\
\text { home market }\end{array}$ \\
$\begin{array}{l}\text { Growing share of educated w orkforce and population } \\
\text { Strong performance in lifelong learning }\end{array}$ & $\begin{array}{l}\text { Lack of in-house innovation by the majority of SM Es } \\
\text { Low share of graduates and enrolments in science } \\
\text { and engineering disciplines }\end{array}$ \\
& Limited number of PhD specializations \\
\hline
\end{tabular}

Source: Adapted from OECD, 2006.

Korea's economy depends more heavily on its manufacturing industry than other countries do (figure 4). Korea started to nurture heavy industries in the late 1960s; the major manufacturing sectors in Korea include electronics (39.5 percent of total manufacturing output), chemicals and petroleum products (16.3 percent), automobiles and shipbuilding (11.9 percent), and steel (9.8 percent).5 It is often said that large firms,

5. Data are for 2007. Source: The Bank of Korea, Economic Statistics System (http://ecos.bok. or.kr) 
called chaebol, have played a core role in Korea's industrial development (e.g., Kim, 1997). Several explanations for Korea's rapid catching-up in technological development have been suggested. Kim (1997) emphasized the power of reverse engineering, which refers to the occurrence of minor innovations and capacity building during imitation.

Figure 4. Korea's Industrial Structure, Compared with a Few Other Countries

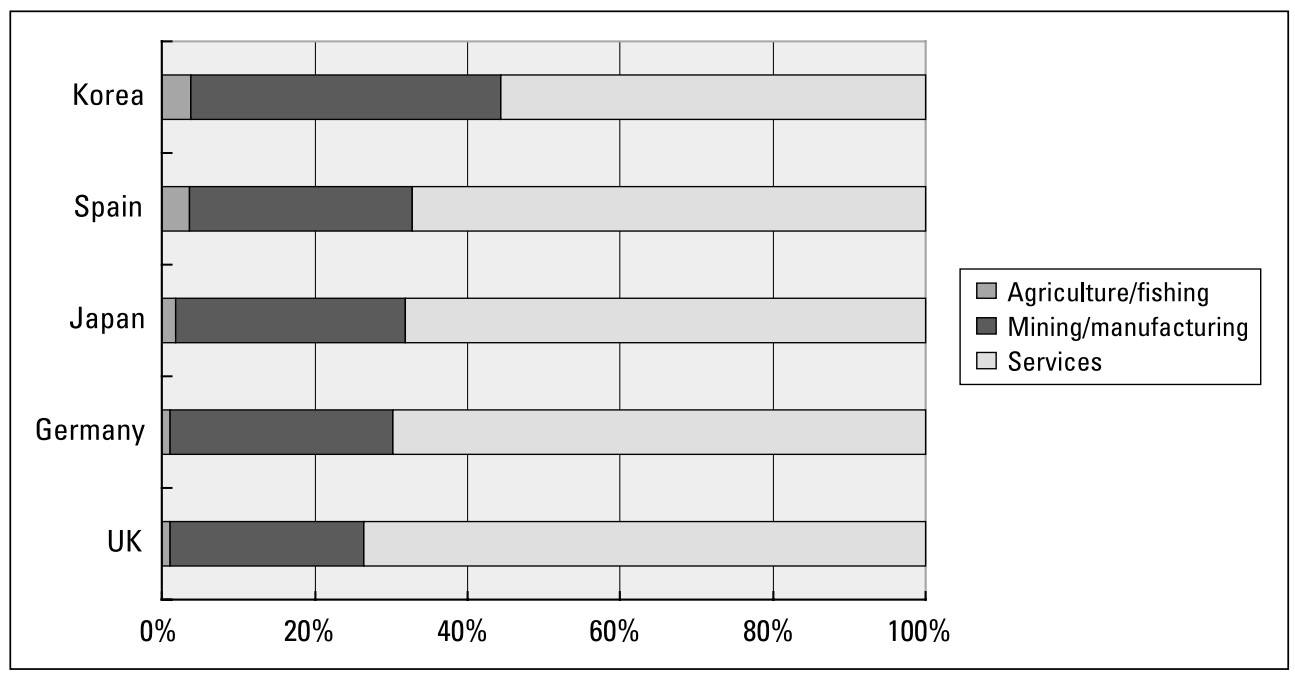

Source: Based on data from KOSIS. Data as of 2004.

The Korean government's national R\&D strategy has been summed up by the slogan "selection (of strategic and promising technologies) and focusing (of available resources on them)" (Lee, 2002). This policy orientation has been criticized by Korean scientists because it may discourage not only academic diversity but also the various industrial possibilities of the future. However, Korea's limited resources and capabilities have justified this policy orientation. As a result, many Korean manufacturing industries became successful "fast seconds" that have enjoyed the advantages of latecomers.

Korea's public R\&D sector is still playing a key role in both basic research and application. It consists of 29 government-funded research institutes (GRIs), divided into four groups according to the purpose of their research. ${ }^{6}$ Korean GRIs have several roles. Firstly, they perform research, employing a large portion $\left(13.7 \%{ }^{7}\right)$ of the total

6. In addition to the GRIs, there are a few national research institutes in the field of science and technology. However, they are more public service agencies than research bodies, supporting ministry functions such as safety and health. Unlike US national institutes, they are not funding agencies. 
$\mathrm{PhD}$ researchers in Korea. Many GRIs are expected to contribute to so-called intermediate technologies, which bridge between basic research and applied research; in other words, they are often asked to provide industry with applicable technologies. In many cases, GRIs combine with firms to form government-funded research consortia to pursue strategic technological development goals, which may sometimes prove very profitable to participating firms.

Secondly, a few large GRIs have in practice become funding agencies, subcontracting research projects to small and medium-sized firms and universities. As a result, they have become centers of research networks, which have further reinforced their importance and power in Korea's NIS. Thirdly, GRIs function as educational institutes and provide a reservoir of human resources in science and technology. As a result, GRIs are located at the center of Korea's NIS.

In the United Kingdom, manufacturing industries' share of GDP peaked at 25.9 percent in 1969 and had declined to 13.5 percent by 2007. Although manufacturing output recovered a little after the recession of 1978-1982, it is generally accepted that the United Kingdom no longer depends largely on manufacturing, especially traditional medium-technology industries such as textiles, steel, shipbuilding, and automobiles. With the decline of manufacturing, the United Kingdom's total business enterprise research and development (BERD) expenditure decreased gradually to only 1.1 percent of GDP in 2004, which is lower than that of other high-income developed countries such as the United States (1.9 percent), Germany (1.75 percent), Japan (2.4 percent) and the OECD average (about 1.5 percent) (OECD, 2007).

The United Kingdom's BERD is concentrated in a few high-tech industries that have strong international competitiveness, in particular pharmaceuticals and medical chemicals (27.6 percent), aerospace (12.8 percent), computer and related activities $(9.5$ percent) and post and telecommunications (8.2 percent), which together represent 58.1 percent of total $\mathrm{BERD}^{8}$. On the other hand, hydrogen energy-related sectors such as electricity, gas, and water supply ( 0.1 percent) and motor vehicles and parts (5.3 percent) spend far less on R\&D than the sectors listed above. The United Kingdom's total public and private spending on R\&D as a percentage of GDP was 1.78 percent in 2004 (OECD, 2007), ${ }^{9}$ so we cannot say that the UK public sector is performing R\&D very actively. Figure 5 shows the share of manufacturing industries in the UK economy.

7. Source: Ministry of Science and Technology, data as of 2005.

8. Source: Office of National Statistics (http://www.ons.gov.uk)

9. By way of comparison, Korea's spending was 2.85 percent of GDP; Japan's 3.15 percent; Germany's 2.55 percent; France's 2.19 percent; and Italy's 1.1 percent (OECD, 2007). 
Figure 5. Output of the UK M anufacturing Industry as percentage of GDP, 1948-2007

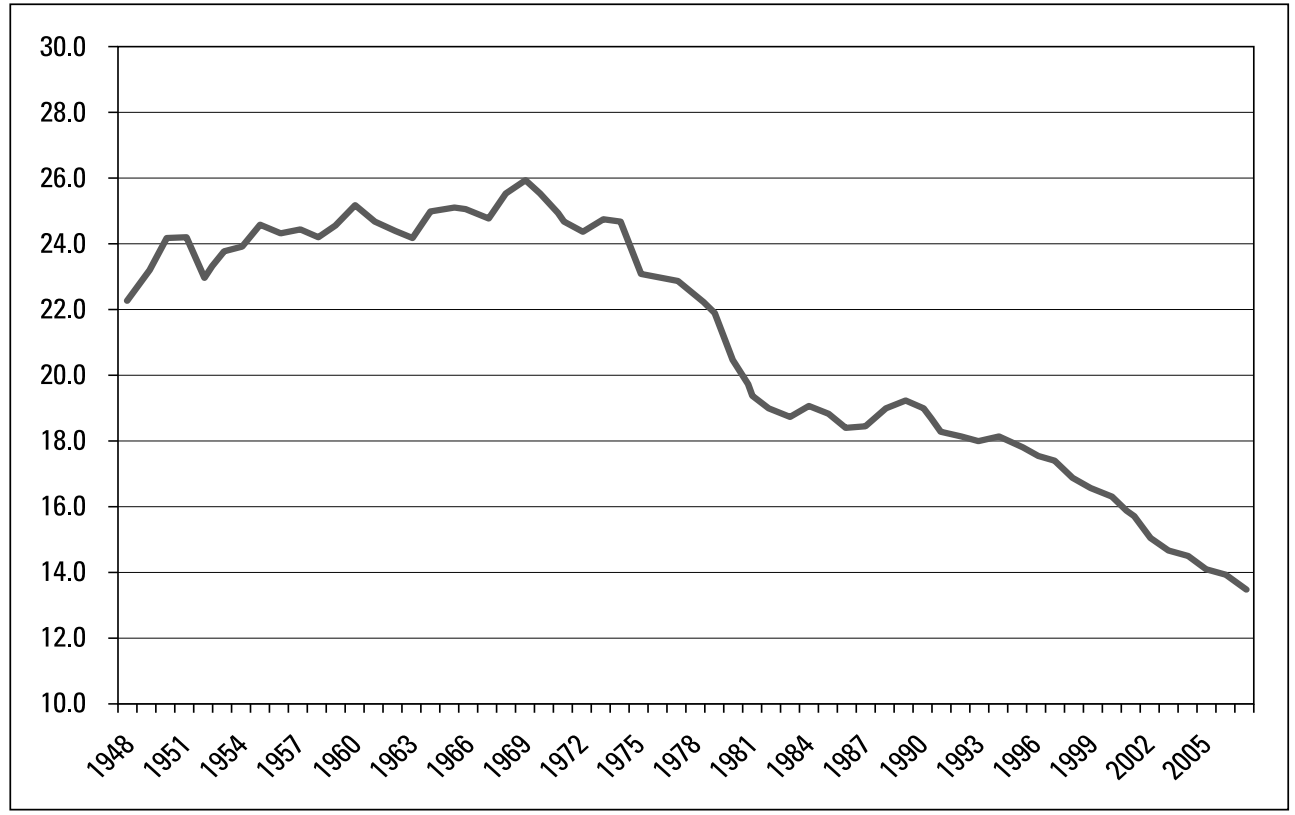

Seasonally adjusted values and $100=2003$ data.

Source: based on data from the Office of National Statistics, with further calculations by the author.

In summary, the United Kingdom's innovation system is characterized by the following: (1) Its manufacturing industries have declined, and so has industrial R\&D, except in the pharmaceutical and aerospace industries. (2) It has a strong science base, excellent universities, and good human resources in science and technology (Lord Sainsbury, 2007). (3) In terms of institutional components (such as the intellectual property right (IPR) system, venture capital and R\&D funding systems), the United Kingdom's NIS is equipped and working reasonably well. (4) The shortage of mediumtechnology mass-manufacturing industries might explain the European Paradox..$^{10}$

\section{Social Selection of Technologies}

The United Kingdom and Korea have focused on fuel cell technologies to provide the basis for an emerging industry, because fuel cells have been generally thought to offer the first mainstream application of hydrogen energy. This is not the case for Iceland; although it might like to develop its own fuel cells industry, it has no related

10. Strong in basic science, weak in commercialization. 
industries and thus no industrial basis for it. Instead, Iceland has decided to import fuel cell vehicles as final products, which has meant that Iceland has had to do little in terms of fuel cells R\&D. Although Iceland depends in part on foreign companies for hydrogen generation technologies and facilities, it nevertheless aims to develop its own hydrogen generation technologies, which will provide it with a good match to its natural environment.

In Korea, it is the concern not only of the government but also of the public to achieve economic growth, in both the short and long term. The Korean people believe that the climate change crisis can provide Korea with a new industrial opportunity, since the resulting global economic reform may open up new markets for sustainable technologies. This perspective has resulted in the government's announcement of a Green Growth Strategy (Presidential Committee on Green Growth, 2009). With automobile manufacturing as one of its most important industries, not only the Korean government but also various research bodies, including GRIs and universities, have paid close attention to fuel cell applications for vehicles. It is therefore understandable that Korea has socially selected fuel cells as an important technological field on which to focus.

There are a number of stakeholders with regard to fuel cells in the United Kingdom, in industry ${ }^{11}$ and academia. Although large energy firms (such as BP and Royal Dutch Shell) have been paying attention to the potential of hydrogen energy either for electricity storage or as a future substitute for oil, it has been seen as just one option out of many. Furthermore, because it requires a huge investment in infrastructure, stakeholders including the UK government have assumed that the time has not yet come to focus on hydrogen energy.

A consensus emerged in the global community after 2003 that fuel cells are promising from an economic perspective in the very near future, and that the fuel cells industry will then encourage other hydrogen energy industries to emerge. Consequently, the UK government has organized stakeholders in the fuel cells area to form a network, ${ }^{12}$ and then perhaps an emerging industry as the next step. However, due to the absence of a major UK-based automobile company, the development of fuel cells technologies has occurred in other product fields than vehicles, such as fuel cells for stationary use, components, and materials. Furthermore, the actual focus has been on hydrogen generation technologies, and researchers in academia and industry have preferred an energy sys-

11. Examples include petrochemicals, electrical power, new and renewable energy, aerospace, and automobile manufacturing.

12. Department of Trade and Industry (DTI) initiated the formation of a stakeholders' network, Fuel Cells UK. This is a policy network of stakeholders rather than an industrial association. 
tem approach to the hydrogen energy transition. This may change in the future as a result of the government's drive for fuel cells, but it will not be easy to create a new mass-manufacturing and mass-employing industry in the UK. Instead, knowledgeintensive small and medium enterprises (SMEs) will probably form a small but highly valued industrial sector.

\section{Diverse Patterns in the Evolution of STI Policies}

In the three-stage model proposed earlier (figure 3), the stages do not always occur in the same order, and there are no clear boundaries between them. Each of the three countries in this study showed a different pattern of evolution.

In Iceland, the Hydrogen Economy Statement was introduced quite suddenly in 1998, though scientists had suggested the energy potential of hydrogen for a long time. In other words, the economic prospects appear to have moved politicians first. All that Iceland needed to do was to collaborate with foreign stakeholders, import products and technologies, and build up hydrogen facilities for deployment. As a consequence, the Icelandic government focused more on policies that would work to improve the social acceptability and public perceptions of hydrogen energy than on R\&D policy. By 2007, nine years after the Hydrogen Statement, the Icelandic government had developed a road map that includes plans for research, development, and deployment. The Icelandic case represents the reverse of the proposed model. A small developed country that has a very limited innovative capability can adopt and apply such a strategy.

In Korea, strategic focusing has been quite successful. Earlier, the Korean government had funded various niche technologies in the field of new and renewable energy, in order to be prepared for possible technological and industrial events and the associated uncertainties. Around 2003, the Korean government became convinced that fuel cells could provide Korean industry with a new opportunity both for the conventional automobile sector and in terms of an emerging industrial sector. Since then, Korea has focused on fuel cells more extensively.

Korea's hydrogen energy policy has continuously emphasized R\&D; the government supports the public research sector directly and the private sector indirectly. Recent policy developments in Korea have related to the economic aspects of hydrogen energy and to the nurturing of industry, while the social aspects have not received much attention from either policy developers or the government until now. In short, one can conclude that Korea is developing hydrogen policies in the earlier stages of the proposed model, a route that can be adopted by late-developing countries that are more concerned with manufacturing industries and economic growth.

The United Kingdom provides a reasonably good match to the three-stage model. 
In line with its free-market tradition, there have been only $\mathrm{R} \& \mathrm{D}$ policies, especially for supporting university research via the Research Councils, which were not particularly strategically focused before 2000. However, since 2003, a key year for hydrogen energy, the UK government has focused on fuel cells, and has made some changes in its STI policy in order to become more strategic, in particular with the launching of the Technology Strategy Board in 2007 (it was first proposed in 2004).

A number of policy research reports have been prepared by various stakeholder networks and policy researchers. Earlier papers emphasized the government's support for R\&D. Later, the UK Roadmap to the Hydrogen Economy emphasized the economic aspects, in addition to sustainability and energy security. Recently, a number of policy researchers across the public sector and universities have been paying greater attention to the socioeconomic aspects of hydrogen energy, which include risks, regulations, social acceptability, and the socio-technical system transition. The UK model is that of a highly developed European country. One might suggest that policy research seems to be running ahead of the actual situation, although arguably that is what policy research is for.

\section{The Role of Government and the Governance of Transition}

The role of government in a country involves many complex aspects, and it varies as a result of political culture, history and tradition, the constitution and other institutions, and the implicit social contract. Despite these complexities, it is still possible to analyze the role of government and its tendency to intervene in the case of hydrogen energy policies.

Since Iceland has an extremely small economy, with no large firms involved in hydrogen energy research, development, or deployment, the Icelandic government has played a key role in every aspect of hydrogen energy. An executive body, Icelandic New Energy, a joint venture of foreign companies and Iceland's national energy company, ${ }^{13}$ was founded in accordance with the Icelandic government's Hydrogen Energy Statement. Although Icelandic New Energy was set up as a company, it is more a quasigovernmental agency, since it has carried out or participated in all the activities related to hydrogen energy in Iceland - such as conducting a social acceptability survey, funding policy research, and developing the Icelandic Roadmap. Iceland's governance structure, both for policy-making and for the transition to the hydrogen economy, is rather simple and small. All the Icelandic hydrogen stakeholders are familiar with each other. Iceland's hydrogen energy policy has been steered by a small forum with partici-

13. Norsk Hydro, Mercedes-Benz, and Shell together have a 50 percent share. 
pants from government ministries, academia, and Icelandic New Energy. As a result, Iceland's policy network on hydrogen energy has the unique characteristic of being more an informal network than a contractual network. ${ }^{14}$

To a certain extent, government action tends to be top-down in style. It matters to what extent government action is carried out in a top-down manner, and how strongly and how often government intervenes in the market. Both the Korean and UK governments have aimed to nurture the emergence of a new industrial sector related to fuel cells by organizing stakeholders not only in industry but also in academia. But there are subtle differences in the ways that they work to achieve policy goals.

In Korea, GRIs and government-funded R\&D consortia play central roles not only in the R\&D network but also in the policy network. The Korean government can readily receive policy inputs from research centers in the consortia, but it is difficult for the relationship between the government and the research centers to be an equal one. When the Korean government developed the Korean Vision and Plan for the Hydrogen Economy, the Ministry of Commerce, Industry, and Energy (renamed the Ministry of Knowledge Economy in 2008) hosted meetings in which the participants included advisory group members who were stakeholders, selectively invited by the Ministry. In addition, according to a number of interviewees, the Ministry may have deliberately tried to steer the policy research. It is certainly possible to claim that the Korean government likes to have everything under its control.

The UK government organized a policy network, Fuel Cells UK, and officials from the Department of Trade and Industry (now the Department for Business, Innovation, and Skills) participated in the network as individual members. As a sponsor of Fuel Cells UK, the Department has been influential in the network. However, most of activities have been carried out independently, and the role of the Department has been confined to guiding and sponsoring. The Department monitored the preparation of the DTI-commissioned E4Tech report (E4Tech 2004) and its provisional contents. However, an interviewee denied that it made any attempt to steer the work.

Since 2004, the UK government has adopted the concept of strategic focusing, especially with regard to emerging sustainable technologies. However, the Technology Strategy Board, which represents this change in government strategy, consists of experts from the private sector still given to exercising executive power. One can argue that the UK government emphasizes the concept of private-public partnerships in the UK's governance structure both in policy-making and in the transition to sustainability.

14. These terms are adopted from Powell and Grodal's (2005) network typology. 


\section{Key Findings}

The purpose of the case studies described here was to see how national innovation systems shape the co-evolution of STI policy and technologies in the early stages of hydrogen energy technology. A range of evidence points to the following conclusions:

1. The NIS of each country has apparently influenced the co-evolution of hydrogen-related technology policies in a different way.

2. Although the three countries share the same global landscape, including the challenges of climate change and energy security as well as scientific achievements, each country's interpretation of the landscape has varied, depending on its NIS, socioeconomic environment, and culture. This has resulted in certain differences in the background of hydrogen energy policies, the strategic aim of policies, and the pattern of evolution of the policies.

3. There are differences in each country's approach to $R \& D$, regarding not only implementation but also strategic focus, which have been influenced by socioeconomic demands, R\&D systems, and, to a significant extent, industrial structure, which is a component of the NIS.

4. The social aspects of an emerging technology have been dealt with in different ways and to a different extent in the three countries.

5. Governance structures, policy-making processes, the role of government, and its tendency to intervene are diverse, depending on the particular government, other executive bodies, and various institutional components of each country's NIS.

In comparing the three countries, it becomes clear that the question of which technology is to be focused upon is shaped by social selection, policy direction, or both. This shows the dependence of technology selection on the NIS, and adds support to the findings that presented the evolution of hydrogen policy in the three countries in broad terms, and in particular linked this to the theoretical notion that the co-evolution of STI policy and emerging technologies takes place within NISs in the form of sociotechnical regimes.

Another result of the comparative analysis, and one that brings together all the findings from this research, is that national innovation systems shape the co-evolutionary processes in STI policies, technologies, and governance. Table 4 summarizes the main findings from this research, with a focus on comparisons. It is possible to identify clear contrasts between the countries. 
Table 4. Comparison of Iceland, Korea, and the United Kingdom

\begin{tabular}{|c|c|c|c|c|}
\hline & & Iceland & Korea & United Kingdom \\
\hline \multirow{6}{*}{$\begin{array}{l}\text { Characteristics of } \\
\text { national innovation } \\
\text { system }\end{array}$} & Economy & Small, developed & Large, lately developed & Very large, developed \\
\hline & $\begin{array}{l}\text { Industry } \\
\text { (sector involved) }\end{array}$ & $\begin{array}{l}\text { Energy intensive } \\
\text { Services } \\
\text { (aluminum) }\end{array}$ & $\begin{array}{l}\text { Manufacturing } \\
\text { (automobiles) }\end{array}$ & $\begin{array}{l}\text { Services } \\
\text { (energy) }\end{array}$ \\
\hline & $R \& D$ bodies & (Not comparable) & $\begin{array}{l}\text { GRIs } \\
\text { Large firms } \\
\text { Universities } \\
\text { SMEs }\end{array}$ & $\begin{array}{l}\text { Universities } \\
\text { Large firms } \\
\text { SMEs }\end{array}$ \\
\hline & Funding & (Not comparable) & $\begin{array}{l}\text { High as a percentage } \\
\text { of GDP } \\
\text { Through ministry } \\
\text { agencies }\end{array}$ & $\begin{array}{l}\text { Low as a percentage } \\
\text { of GDP } \\
\text { Dual support system }\end{array}$ \\
\hline & Strengths & $\begin{array}{l}\text { Public perception, } \\
\text { promptactions }\end{array}$ & $\begin{array}{l}\text { Strategic foc using and } \\
\text { netw orking } \\
\text { Solid manufacturing } \\
\text { industry }\end{array}$ & $\begin{array}{l}\text { Strong science base } \\
\text { Business environment }\end{array}$ \\
\hline & Weaknesses & $\begin{array}{l}\text { Limited } R \& D \text { capacity } \\
\text { due to small economic } \\
\text { size }\end{array}$ & $\begin{array}{l}\text { Notyet at } \\
\text { technological frontier }\end{array}$ & $\begin{array}{l}\text { Declining } \\
\text { manufacturing industry }\end{array}$ \\
\hline \multirow[t]{2}{*}{$\begin{array}{l}\text { Hydrogen energy } \\
\text { transition }\end{array}$} & $\begin{array}{l}\text { Drivers of } \\
\text { transition }\end{array}$ & $\begin{array}{l}\text { Economics } \\
\text { Sustainability }\end{array}$ & $\begin{array}{l}\text { Economics } \\
\text { Energy security }\end{array}$ & $\begin{array}{l}\text { Carbon reduction } \\
\text { Economics } \\
\text { Energy security }\end{array}$ \\
\hline & Public concern & Sustainability & Economic growth & Carbon reduction \\
\hline \multirow{3}{*}{$\begin{array}{l}\text { Hydrogen energy } \\
\text { policy }\end{array}$} & Policy priorities & $\begin{array}{l}\text { Deployment of } \\
\text { hydrogen energy } \\
\text { Social acceptability }\end{array}$ & $\begin{array}{l}R \& D \\
\text { Industry nurturing }\end{array}$ & $\begin{array}{l}\text { R\&D } \\
\text { Transition to } \\
\text { sustainability } \\
\text { Industry nurturing }\end{array}$ \\
\hline & $\begin{array}{l}\text { Evolutionary } \\
\text { stages }\end{array}$ & $\begin{array}{l}\text { Public perception and } \\
\text { social acceptability } \\
\text { Deployment } \\
R \& D\end{array}$ & $\begin{array}{l}\text { R\&D } \\
\text { Early market formation }\end{array}$ & $\begin{array}{l}\text { R\&D } \\
\text { Early market formation } \\
\text { Social acceptability } \\
\text { Socio-technical } \\
\text { transition }\end{array}$ \\
\hline & \begin{tabular}{|l|} 
Policy \\
developers \\
\end{tabular} & $\begin{array}{l}\text { Hydrogen movers and } \\
\text { government }\end{array}$ & $\begin{array}{l}\text { Scientists, industries, } \\
\text { and government }\end{array}$ & $\begin{array}{l}\text { Specialized policy } \\
\text { researchers }\end{array}$ \\
\hline \multirow{2}{*}{ Technology } & $\begin{array}{l}\text { Focused } \\
\text { technology: } \\
\text { Policy driven }\end{array}$ & Hydrogen generation & Fuel cells & Fuel cells \\
\hline & $\begin{array}{l}\text { Focused } \\
\text { technology: } \\
\text { Actual }\end{array}$ & None & Fuel cells & Hydrogen generation \\
\hline \multirow[b]{2}{*}{ Governance } & Nature & Small, primary netw ork & Top down & Public-private partnership \\
\hline & \begin{tabular}{|l|} 
Role of \\
government
\end{tabular} & Almost everything & $\begin{array}{l}\text { Leading industries } \\
\text { Driving } R \& D\end{array}$ & Guiding industries \\
\hline
\end{tabular}

Note: Shared factors in the global landscape are excluded from this table. 
From this comparison it is possible to conclude that the network of research bodies and industrial firms, which are major building blocks of the NIS, have played key roles in the social selection of technologies. In addition, the evolutionary stages model of STI policies for an emerging technology does not seem to apply in the same sequence; different NISs may experience different patterns of evolution. It is also clear that the government is a key actor in the NIS, and policies are one of the most important institutional components of the NIS. The government's role and tendency to intervene are different in each country, as is the effectiveness of policy implementation. Finally, every NIS has both strengths and limitations with regard to the socio-technical transition to hydrogen energy.

\section{CONCLUSION}

STI policies are continuously evolving. The evidence from this study shows that this evolution occurs together with the evolution of technologies, each continuously interacting with the other in a process that can be called co-evolution. National innovation systems shape the patterns of co-evolution, while at the same time being influenced by the global landscape that every NIS shares.

Two major aspects of STI policies emerged from this research. One is the nature of STI policy as a key component of the system, not only in terms of the NIS but also in terms of the socio-technical system, since the convergence of those two systemic perspectives has been suggested. The other is the nature of STI policy-making processes, in which we can come to better understand how governance works - in other words, how the people and institutions involved interact with each other.

STI policy is a key component of an NIS. In a narrow understanding of the concept, STI policy constitutes government activities, and these influence other actors and institutions. In a broader understanding, STI policy represents the following aspects. First of all, it reflects the current status of an NIS and the future goals of society. Second, since STI policy is the result of interactive learning among the various actors involved in the NIS, it represents a consensus among these actors, which often needs to become a broader social consensus, particularly for subjects that are related to large socio-technical systems. As a result, STI policy plays a role as a communication code in the field of science, technology, innovation, and industry. Third, a long-run STI policy can become a part of institutions in the NIS, ${ }^{15}$ and the interconnected bundle of STI policies, together

15. For example, R\&D funding policy initiated and formed the R\&D funding system; technology transfer policy resulted in various technology trade schemes; and incentives for employees to create inventions became a part of the intellectual property rights system. 
with other public policies, can be regarded as forming the policy regime.

One of the key findings from this research is that NISs strongly shape the patterns of co-evolution of STI policies and technological developments. STI policies are the result of interactive social processes, in which various actors such as scientists, government officials, industry actors, nongovernmental organizations, the general public, and foreign actors are involved. In addition, a number of non-human factors influence STI policies, such as the global landscape, technological achievements, the international community and international politics, the policies of other countries, public attitudes toward new technologies, and the broader culture of a country. Even in the case of a government that has strong tendency to intervene and exhibits a top-down manner of policy-making, the resulting STI policy cannot avoid having some interaction with those factors.

Governance structures play an important role in mediating not only policy-making but also system transitions, and this has perhaps been partly successful. In the earlier stages, when an emerging technology is still at the niche level, scientists may be key actors in the governance structure. Later, when the emerging technology is proved to be feasible or believed to be profitable, industry actors take a bigger part in the governance structure. Although the change from one stage to the next may not always be clearly apparent, the role of government certainly evolves as one moves through the stages, from supporting scientific R\&D to nurturing an emerging industry.

It is apparent that participants from diverse sectors will become involved in the governance structure in the next stages. However, except in the case of Iceland, it may be too early to observe the broadened governance structure, although it was possible to see evidence of the evolution in the early stages in the UK and Korean cases. In addition, scientific researchers have still been playing important roles in the governance structures not only for policy-making but also for achieving the necessary socio-technical transitions. The contributions from policy researchers have been significant, especially in the United Kingdom.

In summary, STI policy and policy-making can be characterized as having several aspects: it reflects the national innovation system and socio-technical system; it is the outcome of interactive learning and communication within these systems; and it is continuously evolving, a fitting example of co-evolution.

\section{REFERENCES}

Bush, V. 1945. Science, the endless frontier. Washington, DC: United States Government Printing Office.

E4tech. 2004. A strategic framework for hydrogen energy in the UK. 
European Commission. 2002. Innovation tomorrow. Luxembourg: Office for Official Publications of the European Communities.

Freeman, C., \& Soete, L. 1997. The economics of industrial innovation. Cambridge, MA: MIT Press.

Fuller, S. 2000. Governance of science: Ideology and the future of the open society. Buckingham: Open University Press, Buckingham.

2002. Technological transitions as evolutionary reconfiguration process: a multi-level perspective and a case-study. Research Policy, 31:1257-1274.

Geels, F. W. 2004. From sectoral systems of innovation to socio-technical systems: Insights about dynamics and change from sociology and institutional theory. Research Policy, 33: 897-920.

Glynn, S., Flanagan, K., \& Keenan, M. 2001. Science and governance: Describing and typifying the scientific advice structure in the policy making process-a multi-national study. Luxembourg: European Commission.

Gore, G. 1882. The scientific basis of national progress, including that of morality. London: Williams and Norgate.

Hekkert, M. P., van Giessel, J.-F., Ros, M., \& Wietschel, M. 2005. The evolution of hydrogen research: Is Germany heading for an early lock-in? International Journal of Hydrogen Energy, 30: 1045-1052.

Hughes, T. P. 1983. Networks of Power: Electrification in Western Society, 1880-1930. Baltimore: The Johns Hopkins University Press.

Hughes, T. P. 1989. The Evolution of Large Technological Systems. In Bijker, W. E., Hughes, T. P., \& Pinch, T. (ed.), The Social Construction of Technological Systems: New Directions in the Sociology and History of Technology. London: MIT Press.

Jacobsson, S., \& Bergek, A. 2004. Transforming the energy sector: The evolution of technological system in renewable technology. Industrial and Corporate Change, 13: 815-849.

Jeeninga, H., \& Kets, A. 2004. Evolution of energy policy in the Netherlands: Past, present and future. Building Research \& Information, 32: 38-41.

Kemp, R., Schot, J. \& Hoogma, R. 1998. Regime shifts to sustainability through processes of niche formation: the approach of strategic niche management. Technology Analysis \& Strategic Management, 10: 175-196.

Kemp, R., Rip, A. \& Schot, J. 2001. Constructing transition paths through the management of niches. In Garud, R. \& Karnoe, P. (ed.) Path Dependence and Creation. Mahwah: Lawrence Erlbaum Associates Publishers.

Kim, L. 1993. National system of industrial innovation: Dynamics of capability building in Korea. In R. Nelson (ed.), National innovation systems-a comparative analysis (pp. 357-383). New York: Oxford University Press. 
Kim, L. 1997. Imitation to innovation: The dynamics of Korea's technological learning. Boston: Harvard Business School Press.

Kim, L., \& Nelson, R. 2000. Technology, learning, and innovation: Experiences of newly industrializing economies. Cambridge: Cambridge University Press.

Korean Statistics Information Service (KOSIS) http://www.kosis.kr

Lee, G.-J. 2002. The main contents and strategy of the National Science and Technology Framework. Science and Technology Policy (STEPI), 133: 10-22.

Lord Sainsbury of Turville. 2007. The race to the top: A review of government's science and innovation policies. Norwich: Her Majesty's Stationery Office.

Metcalfe, J. 1998. Evolutionary economics and creative destruction. London: Routledge.

Mytelka, L. K., \& Smith, K. 2002. Policy learning and innovation theory: An interactive and co-evolving process. Research Policy, 31: 1467-1479.

Nelson, R. 1994. The co-evolution of technology, industrial structure, and supporting institutions. Industrial and Corporate Change, 3: 47-63.

Nelson, R., \& Winter, S. G. 1982. An evolutionary theory of economic change. Cambridge, MA: Harvard University Press.

OECD (Organisation for Economic Co-operation and Development). 1963. Science, economic growth and government policy. Paris: OECD.

1971. Science, growth and society. Paris: OECD.

1980. Technical change and economic Policy. Paris: OECD.

1991. Technology and productivity. Paris: OECD.

1992. Technology and the economy. Paris: OECD.

2006. Policy mix for innovation in Iceland. Paris: OECD.

2007. Science, Technology and Industry Outlook. Paris: OECD.

Powell, W. W., \& Grodal, S. 2005. Networks of innovators. In J. Fagerberg, D. Mowery, \& R. R. Nelson (eds.), The Oxford handbook of innovation. Oxford: Oxford University Press, Oxford.

Presidential Committee on Green Growth. 2009. National Strategy on Green Growth.

Rip, A. 2002. Co-evolution of science, technology and society: An expert review for the Bundesministerium Bildung und Forschung's Förderinitiative Politik, Wissenschaft und Gesellschaft. University of Twente.

Rip, A. 2006. A co-evolutionary approach to reflexive governance-and its ironies. In J.-P. Voß, D. Bauknecht, \& R. Kemp (eds.), Reflexive governance for sustainable development: Incorporating unintended feedback in societal problem-solving. Cheltenham: Edward Elgar.

Rip, A., \& Kemp, R. 1998. Technological change. In Human choice \& climate change, Vol. 2. Columbus, OH: Battelle Press.

Zwanenberg, P., \& Millstone, E. 2005. BSE: Risk, Science, and Governance, Oxford: Oxford University Press. 